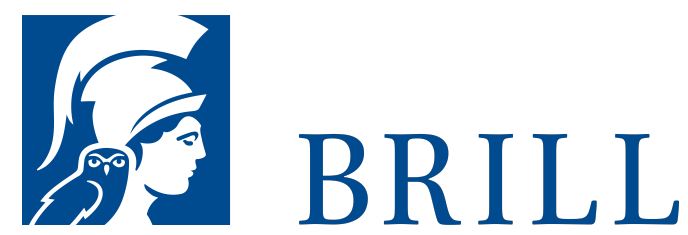

\title{
Authenticating the Words of Jesus \& Authenticating the Activities of Jesus, Volume 1 Authenticating the Words of Jesus
}

\section{Authors: Bruce D. Chilton and Craig A. Evans}

This volume reviews the criteria, assumptions, and methods involved in critical Jesus research. Its purpose is to clarify the procedures necessary to distinguish tradition that stems from Jesus from tradition and interpretation that stem from later tradents and evangelists.

This publication has also been published in paperback, please click here for details.

\section{Readership}

All those interested in Jesus research, early Christianity, early Judaism, and Israel in the first century.

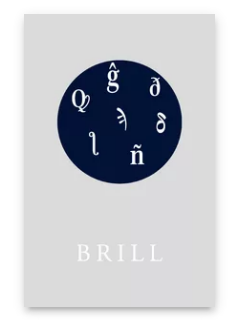

Pages: $x v i, 480$ pp.

Language:

English

Subjects: New

Testament \&

Early Christian

Writings,

Biblical Studies

Publisher: Brill

\section{Series:}

New Testament

Tools, Studies

and Documents,

Volume: 28/1

E-Book (PDF)

Released online:

10 Nov 1998

ISBN: 978-90-

04-41429-7

Hardback

Publication date:

19 Nov 1998

ISBN: 978-90-

04-11301-5

List price

USD \$306.00 
Bruce D. Chilton, Ph.D. (1976) in Biblical Studies, Cambridge University, is Professor of Hebrew Bible and New Testament at Bard College, New York. He has published numerous books and scholarly articles on Jesus and Judaism.

Craig A. Evans, Ph.D. (1983) in Biblical Studies, Claremont Graduate School, is Professor of Biblical Studies and Director of the Graduate Program at Trinity Western University and Senior Research Fellow at Roehampton Institute London. He is the author of numerous books.

For more information see brill.com

\begin{abstract}
Order information: Order online at brill.com +443303330049 | customerservices@brill.com Submission information: brill.com/authors
\end{abstract}

Titles published by Brill | Fink, Brill | mentis or Brill | Schöningh: +49(o)71 5413279216 | brill@brocom.de 